\title{
MAPPING OF RESIDUES OF FIBRINOGEN CLEAVED BY PROTEASE II OF BACILLUS THURINGIENSIS VAR. ISRAELENSIS IMV B-7465
}

\author{
E. M. STOHNIY ${ }^{1}$, V. O. CHERNYSHENKO ${ }^{*}$, N. A. NIDIALKOVA ${ }^{2}$, A. V. REBRIEV ${ }^{1}$, \\ L. D. VARBANETS ${ }^{2}$, V. E. HADZHYNOVA 1 , T. M. CHERNYSHENKO ${ }^{1}$, \\ I. M. KOLESNIKOVA' ${ }^{1}$ E. V. LUGOVSKOY ${ }^{1}$ \\ ${ }^{1}$ Palladin Institute of Biochemistry, National Academy \\ of Sciences of Ukraine, Kyiv; \\ ${ }^{2}$ Zabolotny Institute of Microbiology and Virology, National Academy \\ of Sciences of Ukraine, Kyiv; \\ *e-mail: bio.cherv@gmail.com
}

The limited proteolysis of macromolecules allows obtaining the fragments that preserve the structure and functional properties of the whole molecule and could be used in the study of proteins structure and function. Proteases targeted to fibrinogen and fibrin are of interest as the tool for obtaining of functionally active fragments of fibrin(ogen) and for the direct defibrination in vivo. That is why the aim of the present work was to study the proteolytic action of Protease II (PII) purified from Bacillus thuringiensis var. israelensis IMV B-7465 on fibrinogen.

Hydrolysis products of fibrinogen by PII were analysed by SDS-PAGE under reducing conditions

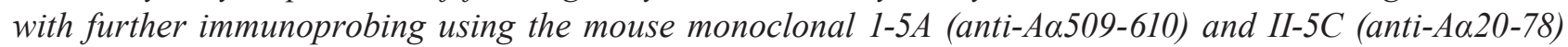

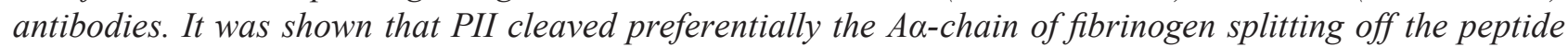
with apparent molecular weight of $10 \mathrm{kDa}$ that corresponded the C-terminal part of A $\alpha$-chain of fibrinogen molecule.

MALDI-TOF analysis of hydrolysis of fibrinogen was performed using a Voyager-DE. Results analyzed by Data Explorer 4.0.0.0 allowed to detect the main peak occurring at mass/charge (M/Z) ratio of 11441 Da. According to «Peptide Mass Calculator» this peptide corresponded to fragment Aa505-610 of fibrinogen molecule. The result showed that PII cleaves the peptide bond AaAsp-Thr-Ala504-Ser505.

Thus, PII can be used for the obtaining of unique fragments of fibrinogen molecule. As far as $\alpha C$ domain contains numerous sites of fibrin intermolecular interactions we can consider PII as a prospective agent for their study and for the defibrination.

Key words: protease, Bacillus thuringiensis, fibrinogen, $\alpha$ C-domain, limited proteolysis.

$\mathrm{P}$ roteases could be found in pathogenic and nonpathogenic species of microorganisms could be targeted to proteins of human and other mammals [1-4]. Fibrinogen as big and labile molecule could be a cleaved by proteases more or less specifically. Fibrinogen-specific metalloproteases were purified from Serratia sp. [5] and Pseudomonas aeruginosa [6], serine proteases from Brevibacillus brevis [7], Bacillus sp. [8], Bacillus cereus [9], Vibrio metschnikovii [10], Aeromonas sobria [11]. Their molecular weight ranges from 30 to $60 \mathrm{kDa}$. Some of them preferentially degrade the $A \alpha$-chain of fibrinogen [9,11], others are targeted to both $A \alpha$ - and $B \beta$-chains of fibrinogen $[6,8]$ or even all three chains of fibrinogen molecule [9]. Most of bacterial fibrinogenases cleave both fibrinogen and polymeric fibrin $[10,11]$. These properties allowed authors to conclude the potential anti-thrombotic use of the enzymes in peptide-based cardiovascular drug development [7-9, 12]. Some of them were already tested in animal models [8] or were cloned for these purposes [13].

Proteases targeted to fibrinogen and fibrin also are of interest as the source for obtaining of physiologically active fragments of fibrin(ogen) and for direct defibrination in vivo. That is why the aim of our work was to study the proteolytic action of PII purified from Bacillus thuringiensis var. israelensis 
IMV B-7465 on human fibrinogen and detection the site(s) of proteolysis on fibrinogen molecule.

\section{Materials and Methods}

Materials. PII was purified from $B$. thuringiensis var. israelensis IMV B-7465 [14]. Fibrinogen used in this study was purified from human citrated blood plasma according to the method described by Varetskaya [15] and was further plasminogen depleted on a Lysine-Sepharose affinity column. Chromogenic substrates used in the study were S2238 (HD-Phe-Pip-Arg-pNA), S2251 (D-Val-Leu-Lys-pNA), S2765 (Z-D-Arg-Gly-Arg-pNA), S2236 (pyro-GluL-Pro-L-Arg-pNA), S2302 (H-D-Pro-Phe-Arg-pNa) and S1040 (Glp-Ala-Ala-Leu-pNa) (Chromogenics, Sweden). Mouse monoclonal 1-6B (anti-Aa509-610) and II-5C (anti-A $\alpha 20-78$ ) antibodies were designed and purified in Protein Structure and functions department of Palladin Institute of biochemistry, NAS of Ukraine.

SDS-PAGE/Western blot. The molecular weights and purity of proteins were determined by SDS-PAGE using 10 or $12 \%$ gels accordingly to Laemli [16]. Hydrolysis products of fibrinogen and fibrin obtained by PII action were also analyzed by SDS-PAGE under reducing conditions. The separated proteins were further transferred to a nitrocellulose membrane in order to specify the bands by immunoprobing. The membrane was blocked with $5 \%$ milk in PBS for an hour, incubated with a mouse monoclonal antibody to B $\beta 26-42$ or to A $\alpha 20-78$ for another hour and then developed with a secondary HRP-labeled goat anti-mouse antibody. The bands were visualized using 0,001 M 4-chloro-1-naphtol solution in $0.5 \mathrm{M}$ Tris- $\mathrm{HCl}$ ) $\mathrm{pH} 7.5$ and $0.03 \% \mathrm{H}_{2} \mathrm{O}_{2}$.

Mass-spectrometry. MALDI-TOF analysis of purified fibrinogenase was performed using a Voyager-DE (Applied Biosystems, USA). $\mathrm{H}^{+}$-matrix ionization of polypeptides under sinapic acid (SigmaAldrich) was used. Results were analyzed by Data Explorer 4.0.0.0 (Applied Biosystems) [17].

Fibrinogenolytic activity of protease. Fibrinogen $(1.5 \mathrm{mg} / \mathrm{ml})$ was mixed with PII $(0.005 \mathrm{mg} / \mathrm{ml})$ in TBS-buffer $\mathrm{pH}$ 7.4. The molar enzyme/substrate ratio was $1: 30$. The mixture was incubated during $5,10,15,20,25,30,40$, and 60 minutes at $25{ }^{\circ} \mathrm{C}$ for SDS-PAGE or for 30 and 60 minutes for the Western blot analysis. The hydrolysis was terminated by the addition of electrophoresis sample buffer containing $2 \%$ SDS, $5 \%$ glycerine and $2 \% \beta$-mercaptoethanol.
Solubilised samples were separated by SDS-PAGE and immunoprobed in Western blot analysis.

Chromogenic substrate assay. Cleavage of chromogenic substrates was studied in microtiter plates by mixing of $0.05 \mathrm{M}$ Tris-HCl buffer of $\mathrm{pH} 7.4$ containing $0.13 \mathrm{M} \mathrm{NaCl}$ with chromogenic substrates in the concentration range from 25 to $160 \mu \mathrm{M}$, and PII $(0.0005 \mathrm{mg} / \mathrm{ml})$, at $25^{\circ} \mathrm{C}$. Amidase activity of PII was continuously monitored at $405 \mathrm{~nm}$. The amount of hydrolyzed substrate was calculated using a molar extinction coefficient of $10.500 \mathrm{M}^{-1} \cdot \mathrm{cm}^{-1}$ for free pNA on reader Multiskan EX [18].

\section{Results and Discussion}

Previously was shown that PII purified from the B. thuringiensis var. israelensis IMV B-7465 could effectively degrade fibrinogen [19]. To identify the region of fibrinogen molecule attacked by PII, the digestion mixture was analyzed by SDS-PAGE under reduced conditions. Plasminogen-free human fibrinogen was incubated with PII at ambient temperature. Upon incubation of fibrinogen with PII, the B $\beta$ - or $\gamma$-chains of the molecule appeared to be the same as those of control fibrinogen whereas the A $\alpha$-chain gradually disappeared, resulting in the formation of a truncated form of about $58 \mathrm{kDa}$ (Fig. 1). The lowmolecular weight fragment of A $\alpha$-chain cleaved-off by PII was detected using SDS-PAGE in $15 \%$ polyacrilamide gel without $\beta$-mercaptoethanol as a polypeptide with molecular weight of about $12 \mathrm{kDa}$ (Fig. 2).

To localize the PII-sensitive area within the fibrinogen $\mathrm{A} \alpha$-chain, we used specific monoclonal antibody to the C-terminal A $\alpha 509-610$ (1-5A) [20] and to the N-terminal A $\alpha 20-78$ (II-5C) [21] portions of fibrinogen $A \alpha$-chain for immunoprobing of SDSPAGE separated proteins of the digestion mixture (Fig. 3, 4). In the case of I-5A antibody use the traces of the native fibrinogen $\mathrm{A} \alpha$-chain which was slightly visible after 30 minutes of incubation with PII and almost completely disappeared after 60 minutes while the low-molecular weight fragment of $A \alpha-$ chain appeared (Fig. 3). On the other hand, when II$5 \mathrm{C}$ antibody was used we observed high-molecular weight fragment of $\mathrm{A} \alpha$-chain that contain $\mathrm{N}$-terminal portions of the $A \alpha$-chain (Fig. 4).

Thus we can conclude that PII selectively degrades $A \alpha$-chain of fibrinogen releasing a polypeptide with average molecular weight of about $12 \mathrm{kDa}$. This molecular weight was checked by MALDI-TOF 


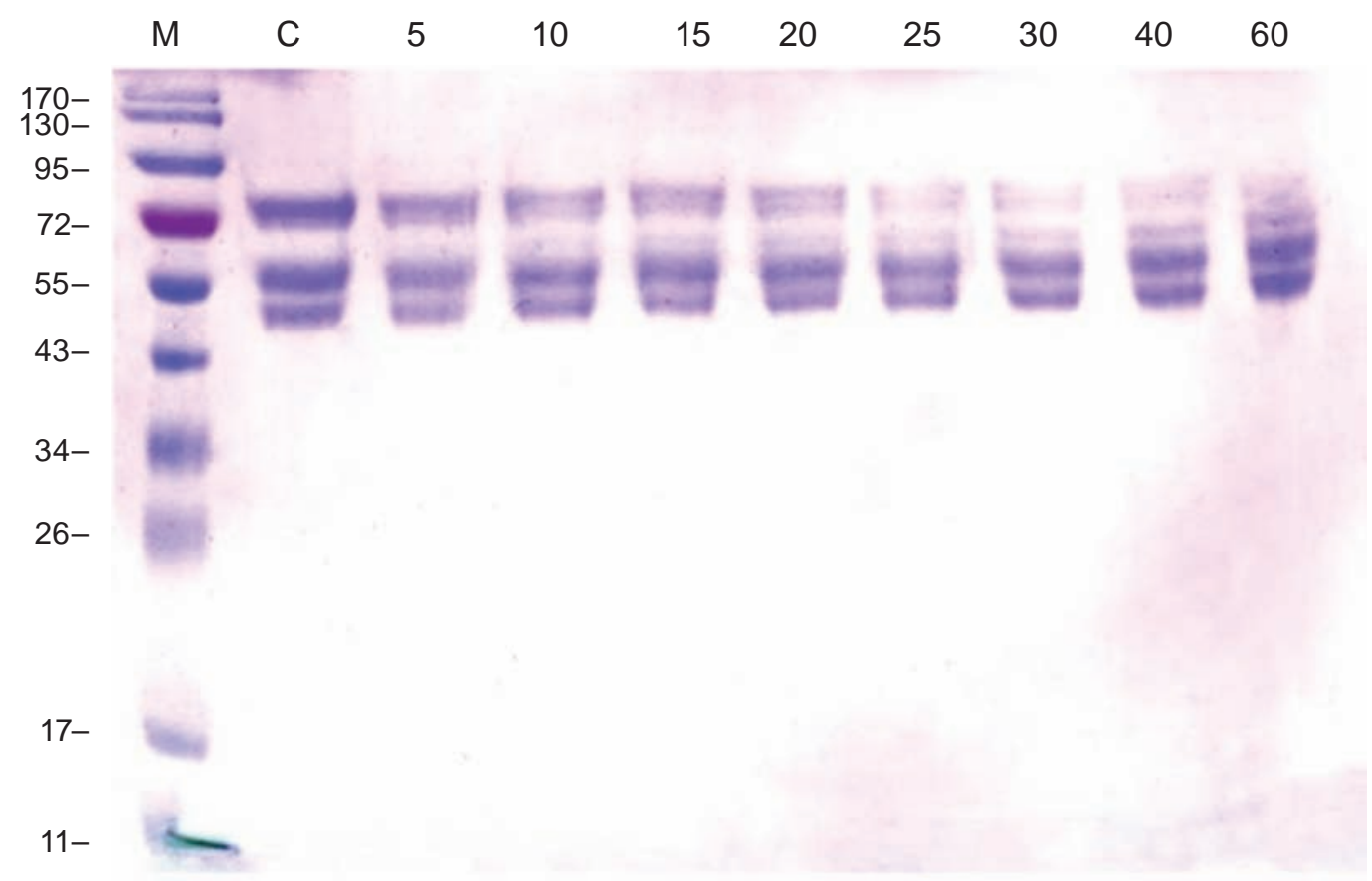

Fig. 1. SDS-PAGE of fibrinogen $(1.5 \mathrm{mg} / \mathrm{ml})$ digested by PII $(0.005 \mathrm{mg} / \mathrm{ml})$. Incubation time $5-60 \mathrm{~min}$. C-native fibrinogen; $M$ - molecular weight markers. Samples were analyzed under reducing conditions $(0.2 \%$ $\beta$-mercaptoethanol)

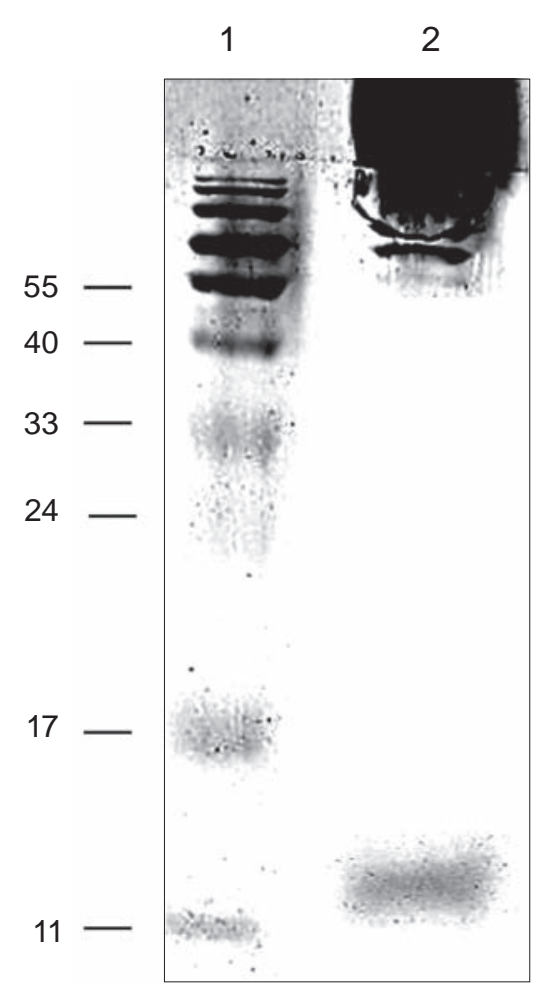

Fig. 2. SDS-PAGE of fibrinogen digested by PII $(0.005 \mathrm{mg} / \mathrm{ml})$ during $60 \mathrm{~min} .1$ - molecular weight markers; 2 - hydrolyzed fibrinogen

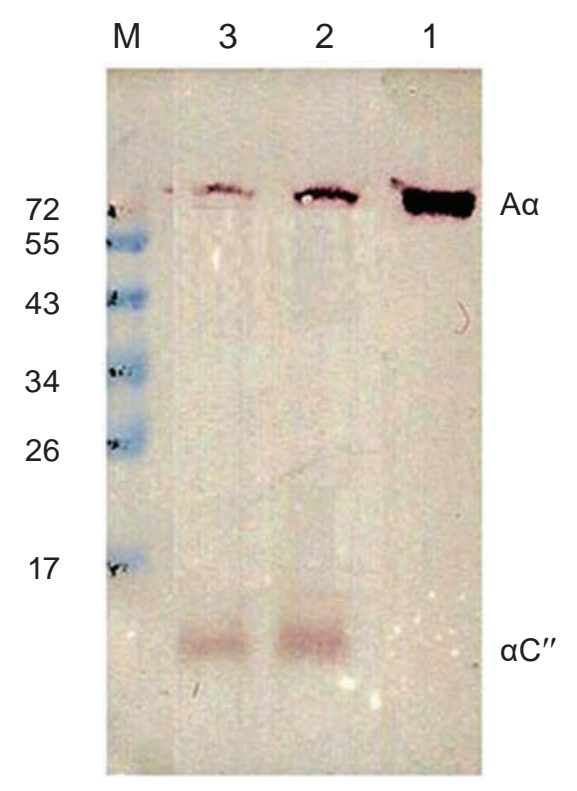

Fig. 3. Western blot analysis of fibrinogen digested by PII $(0.01 \mathrm{mg} / \mathrm{ml})$. M-molecular weight markers; 1 - native fibrinogen; 2 - fibrinogen after 30 min of hydrolysis; 3 - fibrinogen after 60 min of hydrolysis. Samples were analyzed under reducing conditions and immunoprobed by anti-fibrinogen antibody 1-5A (anti-Aa509-610) targeted to the C-terminal parts of $\alpha C$-domains 


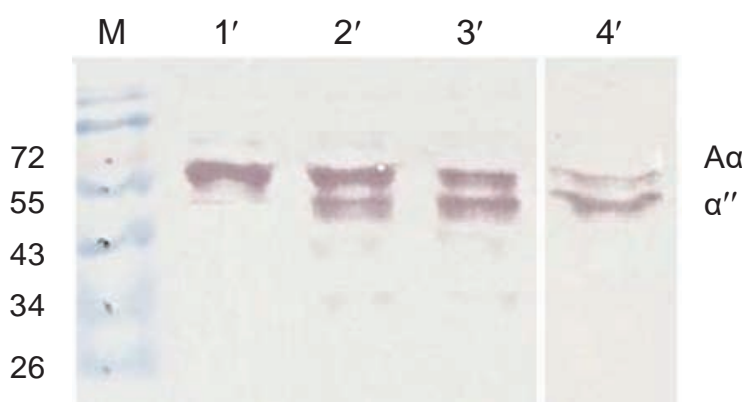

Fig. 4. Western blot analysis of fibrinogen digested by PII $(0.01 \mathrm{mg} / \mathrm{ml})$. M-molecular weight markers; 1 - native fibrinogen; 2 - fibrinogen after 30 min of hydrolysis; 3 - fibrinogen after 60 min of hydrolysis. Samples were analyzed under reducing conditions and immunoprobed by anti-fibrinogen antibody II-

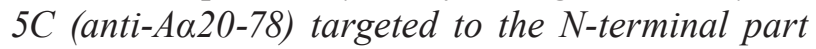
of $\alpha$-chain

analysis. We compared the spectra of the mixture of fibrinogen with PII before the incubation (A) and after 60 min of incubation (B). The main peak that appeared after hydrolysis occurred at mass/charge (M/Z) ratio of approximately 11441 (Fig. 5) generated by a polypeptide of $11.441 \mathrm{kDa}$ bearing one charge. Other peaks were minor and did not repeat themselves across multiple spectra.

Analysis of C-terminal portions of the finbrinogen A $\alpha$-chain in "Peptide Mass Calculator" (http://www.peptidesynthetics.co.uk/tools/) showed that peptide with molecular weight of $11445.317 \mathrm{Da}$ corresponded to the peptide "stgktfpgffspmlgefvsetesrgsesgiftntkessshhpgiaefpsrgksssyskqftsstsynrgdstfesksykmadeagseadhegthstkrghaksrpv", that could be formed after cleavage of the peptide bond AaAsp-Thr-Ala504-Ser505.

Surprisingly this observation showed that PII predominantly cleaves fibrinogen at the carboxyl side of the non-polar hydrophobic amino acid Alanine. To approve this conclusion we performed the chromogenic substrate assay and compared the activity of PII towards chromogenic substrates S2238 (H-D-Phe-Pip-Arg-pNA), S2251 (D-Val-Leu-LyspNA), S2302 (H-D-Pro-Phe-Arg-pNa), S1040 (GlpAla-Ala-Leu-pNa). We showed that the PII was more specific to peptide bonds formed by C-group of hy- drophobic Leucine (as in S1040 substrate) and was less specific to the bond formed by C-group of positively charged Lysine proceeded by the hydrophobic Leucine (as in S2251 substrate) (Fig. 6). Proteases targeted to peptide bonds formed by C-groups of hydrophobic amino acids are not numerous but Leucine-specific proteases were reported [22] and one of such proteases was purified from Bacillus sp. [23]. It is also known that substrates containing Alanine or Valine in the P1 position are specific for elastase [24]. So the data on specificity of PII confirmed the data of MALDI-TOF analysis of fibrinogen-derived peptide formed by this enzyme.

Fibrinogen $\alpha \mathrm{C}$-regions are distant $\mathrm{C}$-terminal parts of $A \alpha$-chains (A $\alpha 392-610$ ) that binds tothe central portion of the molecule. After the conversion of fibrinogen to fibrin $\alpha \mathrm{C}$-regions dissociate from the central region and are available for intermolecular interaction [25-27]. These parts of molecule take part in polymerisation of fibrin [28], they contain ArgGly-Asp residues (A $\alpha 572-574)$ that interacts with platelet receptors [29] and support endothelial cells migration and proliferation [30]. Using the forms of fibrinogen with removed $\alpha \mathrm{C}$-regions is known as an approach for the study of their role in biological processes [31, 32]. That is why characterisation of new proteases targeted to the residues of $\alpha \mathrm{C}$-regions is of interest for the study of fibrinogen structure and functions.

On Fig. 7 are shown C-terminal residues of fibrinogen $A \alpha$-chain with points of proteolysis by several enzymes. Plasmin that is serine protease involved in fibrinolysis has numerous proteolytic sites at the $\alpha \mathrm{C}$-regions [33]. Among them Lys509-Thr510 and Lys584-Met585 are located in distant C-terminal parts of the A $\alpha$-chains [34].

There are the list of reports on proteases that attack $\alpha \mathrm{C}$-regions but the specificity is not revealed for most of these enzymes [35-37]. Recently described serine protease from the venom of Echis multisquamatis cleaves Arg491-His492 peptide bond releasing peptide Aa492-610 [38]. Macrophage elastase characterised in the work [39] attacks Glu520-Phe521. Hementin purified from the posterior salivary glands of the leech Haementeria ghilianii is able to cleave the peptide bond Ala498-Ala499 [40]. Remarkably hementin is specific to the bond formed by C-terminal group of the hydrophobic Alanine. According to our results PII of B. thuringiensis var. israelensis IMV B-7465 cleaved-off peptide A $\alpha$ Ala505-Ser610 from fibrinogen molecule. 


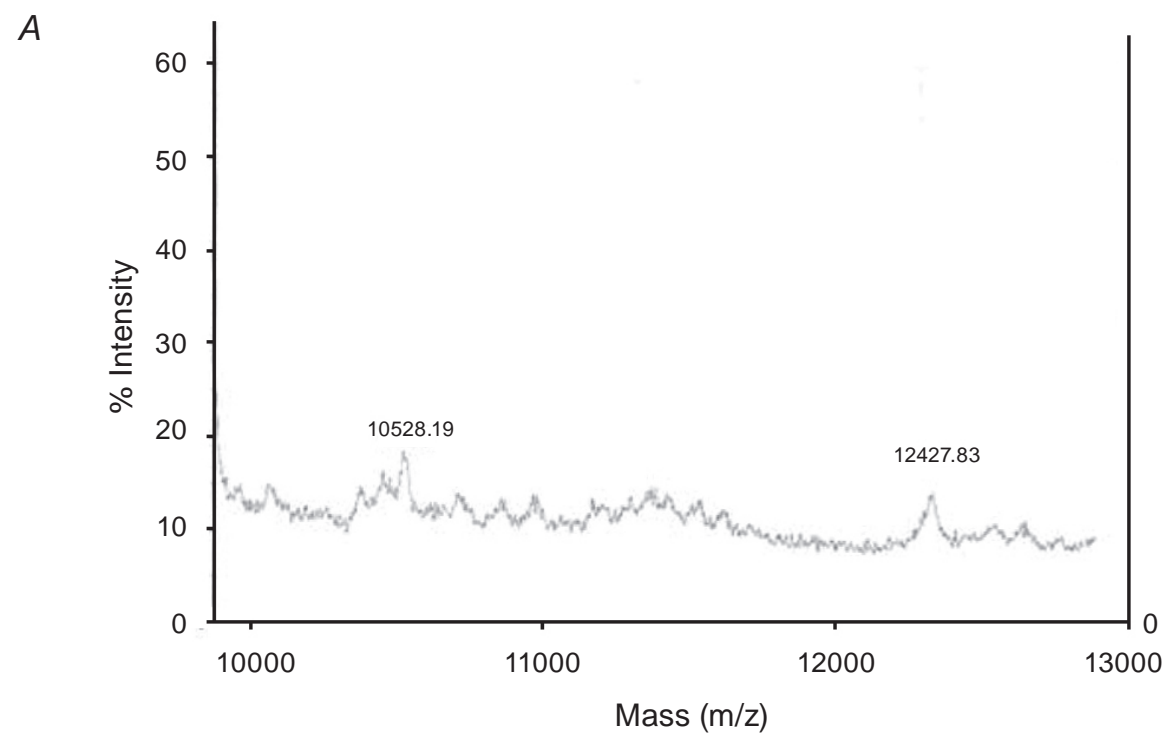

$B$

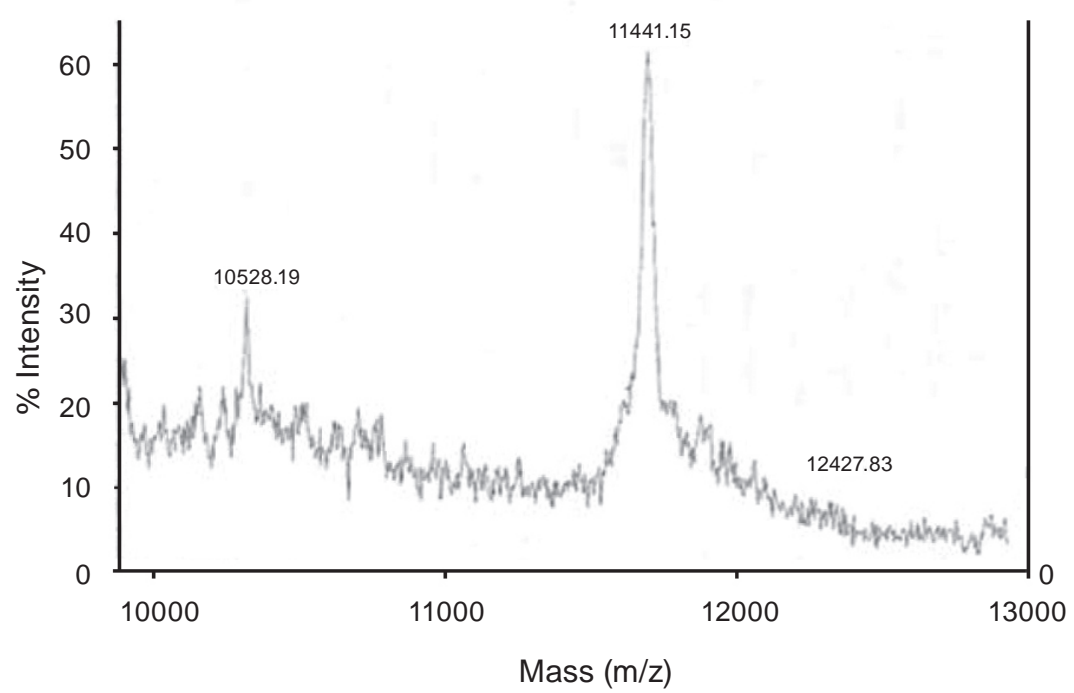

Fig. 5. MALDI-TOF spectrum of fibrinogen hydrolyzed by PII. A-MALDI-TOF spectrum before hydrolysis; $B$ - MALDI-TOF spectrum after hydrolysis

A new fibrinogen-specific protease from the B. thuringiensis var. israelensis IMV B-7465 was described. It was established that the target of its proteolytic action on fibrinogen is AaAla494Ser495 peptide bond. As far as proteases with such specificity have not been described previously we could suggest its potential use for obtaining of the unique digested forms of fibrinogen. Fibrinogen desA $\alpha 505-610$ could be used in the study of the role of distant C-terminal portions of fibrinogen $\alpha \mathrm{C}$ regions in the protein and cellular interactions. Further studies of coagulability of digested fibrinogen as well as the study of PII action in vivo will allow to assume the possible use of PII as anticoagulant agent.

\section{Addendum}

All authors contribute to the work equally. Eugene Stohniy performed SDS-PAGE and Western Blot experiments, Volodymyr Chernyshenko contributed to the study design and acquisition of data. Natalya Nidialkova purified and characterized the enzyme. Andriy Rebriev performed MALDI-TOF analysis. Tamara Chernyshenko purified and characterized human fibrinogen used in the study. Veronika Hadzhynova and Iryna Kolesnikova constructed the monoclonal antibody that was used in study. Eduard Lugovskoy and Liudmyla Varbanets contributed to the analysis and interpretation of data, as well as the drafting of the article. All authors approved the final version of the article to be published. 


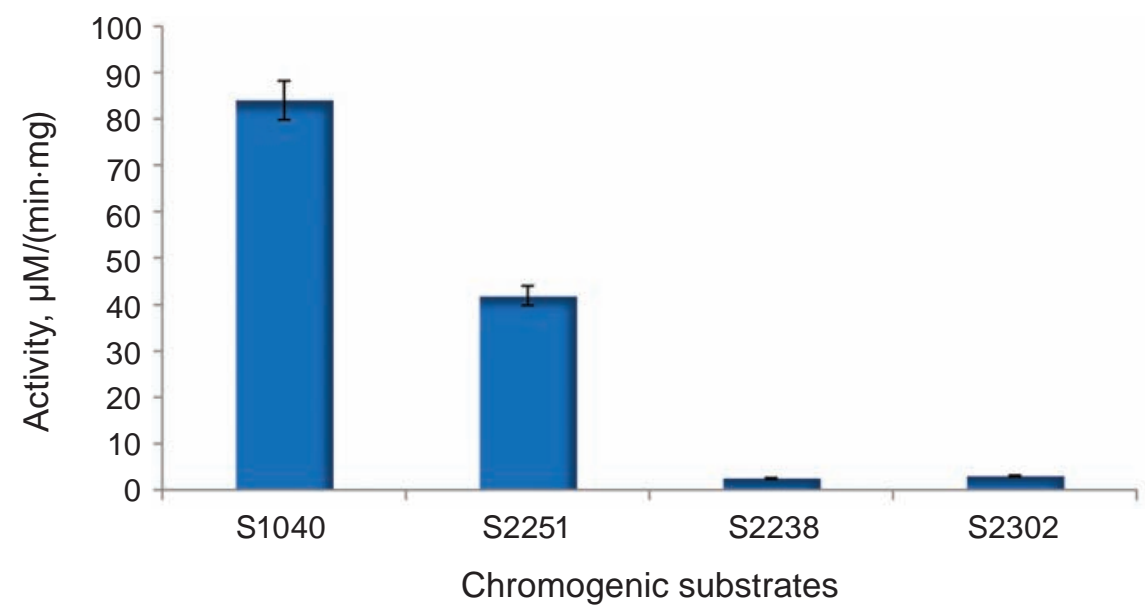

Fig. 6. Amidase activity of PII towards some chromogenic substrates: S2238 (H-D-Phe-Pip-Arg-pNA), S2251 (D-Val-Leu-Lys-pNA), S2302 (H-D-Pro-Phe-Arg-pNa), S1040 (Glp-Ala-Ala-Leu-pNa)

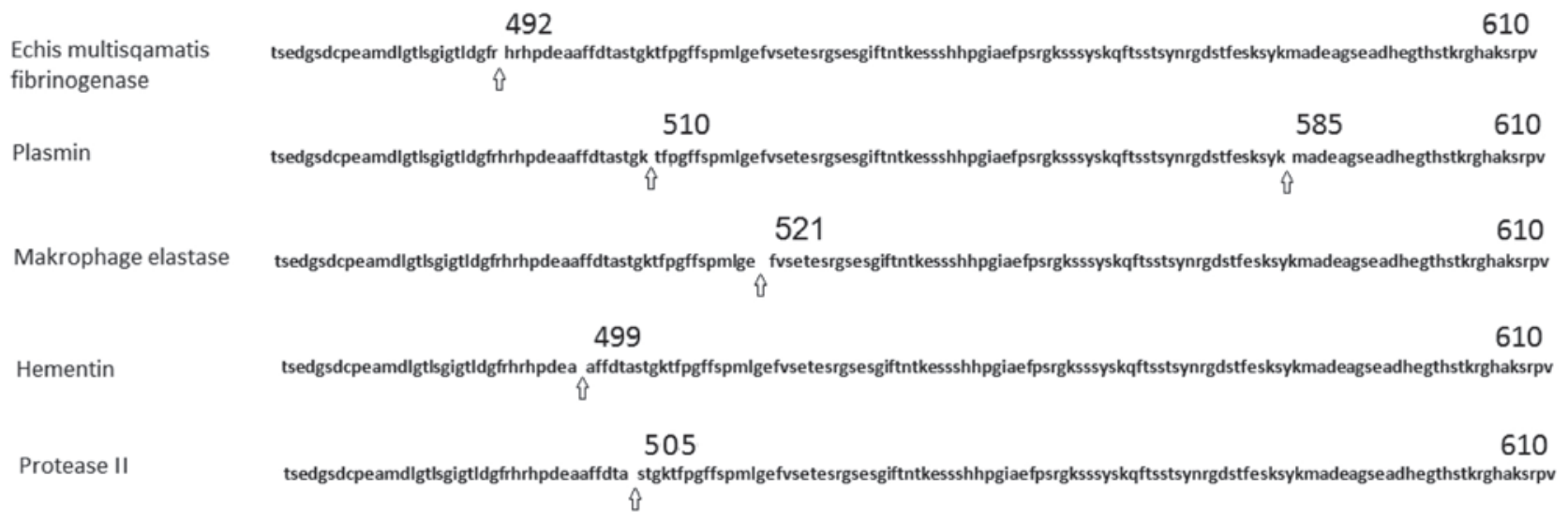

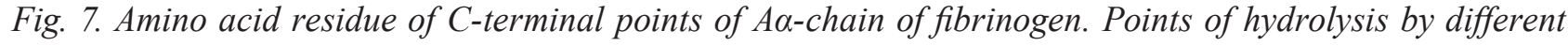
proteases are marked with the spaces. Terminal amino acids of resulting peptides are marked

\section{References}

1. Hoge R., Pelzer A., Rosenau F., Wilhelm S. Weapons of a pathogen: Proteases and their role in virulence of Pseudomonas aeruginosa. In Current Research, Technology and Education Topics in Applied Microbiology and Microbial Biotechnology, Ed by A. Medes-Vilas, 2010. Pharmatex. P. 383-395.

2. Khan NA, Jarroll EL, Panjwani N, Cao Z, Paget TA. Proteases as markers for differentiation of pathogenic and nonpathogenic species of Acanthamoeba. J Clin Microbiol. 2000; 38(8): 2858-2861.

3. Matseliukh OV, Nidialkova NA, Varbanets LD, Andreeva NO, Shepelevych VV, Zelena PP, Yumyna JM. Ability of microorganisms from different ecological niches to hydrolyze the insoluble proteins. Mikrobiol Zh. 2015; 77(3): 16-22. (In Ukrainian).

4. Peng Y, Yang X, Zhang Y. Microbial fibrinolytic enzymes: an overview of source, production, properties, and thrombolytic activity in vivo. Appl Microbiol Biotechnol. 2005; 69(2): 126132.

5 Lakshmi Bhargavi P, Prakasham RS. A fibrinolytic, alkaline and thermostable metalloprotease from the newly isolated Serratia sp RSPB11. Int J Biol Macromol. 2013; 61: 479486.

6. Fricke B, Parchmann O, Kruse K, Rücknagel P, Schierhorn A, Menge S. Characterization and purification of an outer membrane metalloproteinase from Pseudomonas aeruginosa with fibrinogenolytic activity. Biochim Biophys Acta. 1999; 1454(3): 236-250. 
7. Majumdar S, Sarmah B, Gogoi D, Banerjee S, Ghosh SS, Banerjee S, Chattopadhyay P, Mukherjee AK. Characterization, mechanism of anticoagulant action, and assessment of therapeutic potential of a fibrinolytic serine protease (Brevithrombolase) purified from Brevibacillus brevis strain FF02B. Biochimie. 2014; 103: 50-60.

8. Mukherjee AK, Rai SK, Thakur R, Chattopadhyay P, Kar SK. Bafibrinase: A non-toxic, non-hemorrhagic, direct-acting fibrinolytic serine protease from Bacillus sp. strain AS-S20-I exhibits in vivo anticoagulant activity and thrombolytic potency. Biochimie. 2012; 94(6): 1300-1308.

9. Majumdar S, Dutta S, Das T, Chattopadhyay P, Mukherjee AK. Antiplatelet and antithrombotic activity of a fibrin(ogen)olytic protease from Bacillus cereus strain FF01. Int J Biol Macromol. 2015; 79: 477-489.

10. Park JY, Park JE, Park JW, Yoon SM, Lee JS. Purification and characterization of a novel alkaline serine protease secreted by Vibrio metschnikovii. Int J Mol Med. 2012; 29(2): 263268.

11. Imamura $T$, Nitta $H$, Wada $Y$, Kobayashi $H$, Okamoto K. Impaired plasma clottability induction through fibrinogen degradation by ASP, a serine protease released from Aeromonas sobria. FEMS Microbiol Lett. 2008; 284(1): 3542.

12. Reshma CV, Zuhara KF. Response surface methodology based optimization of a new isolate Bacillus pumilus ZR LS S2 with fibrinolytic activity. Br Biotechnol J. 2015; 6(2): 51-61.

13. Ahn MJ, Ku HJ, Lee SH, Lee JH. Characterization of a novel fibrinolytic enzyme, BsfA, from Bacillus subtilis ZA400 in Kimchi reveals its pertinence to thrombosis treatment. J Microbiol Biotechnol. 2015; 25(12): 2090-2099.

14. Matselyukh OV, Nidialkova NA, Varbanets LD. Purification and physicochemical properties of Bacillus thuringiensis IMB B-7324 peptidase with elastolytic and fibrinolytic activity. Ukr Biokhim Zhurn. 2012; 84(6): 25-36. (In Ukrainian).

15. Varetskaia TV. Preparation of a fibrin monomer and studies on some of its properties. $U k r$ Biokhim Zhurn. 1965; 37(2): 194-206. (In Ukrainian).
16. Laemmli UK. Cleavage of structural proteins during the assembly of the head of bacteriophage T4. Nature. 1970; 227(5259): 680-685.

17. Chapman J. R. Mass Spectrometry of Proteins and Peptides. Humana Press, 2000, 538.

18. Gershkovich AA, Kibirev VK. Chromogenic and fluorogenic peptide substrates of proteolytic enzymes. Bioorg Khim. 1988; 14(11): 1461-1488. (In Russian).

19. Nidialkova N.A., Varbanets L.D. A bacterial strain Bacillus thuringiensis var. israelensis producer of extracellular fibrinolytic peptidase. UA Patent. (In Ukrainian).

20. Hadzhynova VE, Kolesnikova IM, Pozniak TA, Kostiuchenko OP. Monoclonal antibody I-5A against AlphaC-region of fibrin(ogen) molecule and their practical use. In: "Hot Topics on Biochemistry and Biotechnology - 2015". Kyiv, 2015. Sanchenko. P. 63.

21. Pozniak TA, Kolesnikova IN, Litvinova LM, Kostiuchenko OP, Urvant LP, Khadzhynova VE, Lugovskoi EV, Komisarenko SV. Monoclonal antibodies specific to the E-region of human fibrin(ogen). Report Natl Acad Sci Ukraine. 2014; 4: 162-167. (In Ukrainian).

22. Duncan EA, Brown MS, Goldstein JL, Sakai J. Cleavage site for sterol-regulated protease localized to a leu-Ser bond in the lumenal loop of sterol regulatory element-binding protein-2. J Biol Chem. 1997; 272(19): 12778-12785.

23. Feder J, Schuck JM. Studies on the Bacillus subtilis neutral-protease- and Bacillus thermoproteolyticus thermolysin-catalyzed hydrolysis of dipeptide substrates. Biochemistry. 1970; 9(14): 2784-2791.

24. Hung SH, Hedstrom L. Converting trypsin to elastase: substitution of the S1 site and adjacent loops reconstitutes esterase specificity but not amidase activity. Protein Eng. 1998; 11(8): 669673.

25. Weisel JW, Medved L. The structure and function of the alpha $\mathrm{C}$ domains of fibrinogen. Ann N Y Acad Sci. 2001; 936: 312-327.

26. Tsurupa G, Hantgan RR, Burton RA, Pechik I, Tjandra N, Medved L. Structure, stability, and interaction of the fibrin(ogen) alphaC-domains. Biochemistry. 2009; 48(51): 12191-12201.

27. Collet JP, Moen JL, Veklich YI, Gorkun OV, Lord ST, Montalescot G, Weisel JW. The alphaC domains of fibrinogen affect the structure of 
the fibrin clot, its physical properties, and its susceptibility to fibrinolysis. Blood. 2005; 106(12): 3824-3830.

28. Gorkun OV, Veklich YI, Medved LV, Henschen AH, Weisel JW. Role of the alpha C domains of fibrin in clot formation. Biochemistry. 1994; 33(22): 6986-6997.

29. Hawiger J, Kloczewiak M, Bednarek MA, Timmons S. Platelet receptor recognition domains on the alpha chain of human fibrinogen: structure-function analysis. Biochemistry. 1989; 28(7): 2909-2914.

30. Yakovlev S, Mikhailenko I, Tsurupa G, Belkin AM, Medved L. Polymerisation of fibrin $\alpha \mathrm{C}$-domains promotes endothelial cell migration and proliferation. Thromb Haemost. 2014; 112(6):1244-1251.

31. Sato H, Weisel JW. Polymerization of fibrinogen-derived fragment $\mathrm{X}$ and subsequent rearrangement of fibers. Thromb Res. 1990; 58(3): 205-212.

32. Gorkun OV, Henschen-Edman AH, Ping LF, Lord ST. Analysis of A alpha 251 fibrinogen: the alpha $\mathrm{C}$ domain has a role in polymerization, albeit more subtle than anticipated from the analogous proteolytic fragment X. Biochemistry. 1998 Nov 3; 37(44): 15434-15441.

33. Cottrell BA, Doolittle RF. The amino acid sequence of a 27-residue peptide released from the alpha-chain carboxy-terminus during the plasmic digestion of human fibrinogen. Biochem Biophys Res Commun. 1976; 71(3): 754-761.

34. Mihalyi E. Kinetics and molecular mechanism of the proteolytic fragmentation of fibrinogen. Ann N Y Acad Sci. 1983; 408: 60-70.

35. Harty DW, Farahani RM, Simonian MR, Hunter L, Hunter N. Streptococcus gordonii
FSS2 Challisin affects fibrin clot formation by digestion of the $\alpha \mathrm{C}$ region and cleavage of the $\mathrm{N}$ -terminal region of the $\mathrm{B} \beta$ chains of fibrinogen. Thromb Haemost. 2012; 108(2): 236-246.

36. Lee SY, Kim JS, Kim JE, Sapkota K, Shen MH, Kim S, Chun HS, Yoo JC, Choi HS, Kim MK, Kim SJ. Purification and characterization of fibrinolytic enzyme from cultured mycelia of Armillaria mellea. Protein Expr Purif. 2005; 43(1): 10-17.

37. Gomes MS, Naves de Souza DL, Guimarães DO, Lopes DS, Mamede CC, Gimenes SN, Achê DC, Rodrigues RS, Yoneyama KA, Borges MH, de Oliveira F, Rodrigues VM. Biochemical and functional characterization of Bothropoidin: the first haemorrhagic metalloproteinase from Bothrops pauloensis snake venom. J Biochem. 2015; 157(3): 137-149.

38. Chernyshenko VO. Limited proteolysis of fibrinogen by fibrinogenase from Echis multisquamatis venom. Protein J. 2015; 34(2): 130-134.

39. Hiller O, Lichte A, Oberpichler A, Kocourek A, Tschesche H. Matrix metalloproteinases collagenase-2, macrophage elastase, collagenase-3, and membrane type 1-matrix metalloproteinase impair clotting by degradation of fibrinogen and factor XII. J Biol Chem. 2000; 275(42): 3300833013.

40. Kirschbaum NE, Budzynski AZ. A unique proteolytic fragment of human fibrinogen containing the A alpha $\mathrm{COOH}$-terminal domain of the native molecule. J Biol Chem. 1990; 265(23): 13669-13676.

Received 25.03.2016 